\title{
Hætta á neyðarástandi á Landspítala
}

\section{Engilbert Sigurðsson}

ritstjóri og ábyrgðarmaður Læknablaðsins, prófessor í geðlæknisfræði við læknadeild Háskóla Íslands, yfirlæknir við geðsvið Landspítala

engilbs@landspitali.is

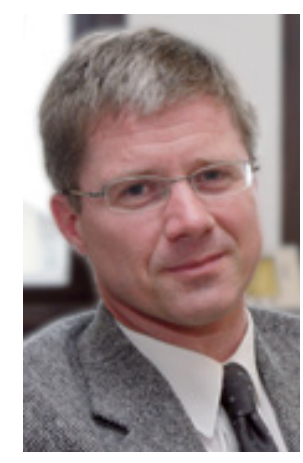

Stundum er haft á orði að veikur maður eigi aðeins eina ósk. Pegar sjúkdómar ógna lífi og einhver von er um lækningu, er pað reynsla lækna að hinn sjúki og aðstandendur vilja allt til vinna að lækning takist, jafnvel pegar lífshorfur eru taldar í mánuðum en ekki árum. Lífstaugin er sterk. Раð er betra аð vera lifandi en dauður í huga flestra. Sem betur fer er pað lítill hluti hverrar pjóðar sem á ástvini sem glíma við alvarleg veikindi eða horfast í augu við nálægð dauðans á hverjum tíma. Margir eiga pví erfitt með að átta sig á hve ófullnægjandi húsnæði og starfsumhverfi á Landspítala er orðið. Раð er raunar alls ekki sjálfgefið að pjóð sem telur aðeins 320 púsund manns hafi forsendur til að reka háskólasjúkrahús með nægum mannauði til að geta greint og meðhöndlað langflesta sjúkdóma sem ógna lífi og heilsu manna. Sífellt fleira bendir nú til að pessar forsendur kunni að bresta hér á landi á næstu mánuðum.

Margs konar ógnir steðja nú að mannauði Landspítala. Sumar má leysa með bættum kjörum, aðbúnaði og vinnutíma. Pær lausnir kosta pó allar meiri fjármuni en eru í sjónmáli í fjárlögum ársins 2013. Eftir aðeins fjórar vikur, hinn 1. mars, munu uppsagnir 20\% hjúkrunarfræðinga spítalans taka gildi nema lausn finnist með fjármögnun stofnanasamnings. Vert er pó að geta pess að könnun mannauðssviðs Landspítala á árinu 2012 sýndi mun meiri óánægju meðal sérfræðilækna og almennra lækna en hjúkrunarfræðinga á Landspítala. ${ }^{1}$ Hjá læknunum voru nær öll svör á rauðu, með öðrum orðum á svokölluðu aðgerðastigi.
Aðrar ógnir eru pess eðlis að pær verða ekki leystar með stofnanasamningum eða í kjarasamningum. Flestir landsmenn vita vegna mikillar umræðu á síðastliðnu ári að tækjakostur Landspítala úreldist hratt. Staða tækja ógnar nú pegar getu lækna til skjótrar greiningar og meðferðar svo sem á hjartasjúkdómum í Fossvogi. ${ }^{2}$ Einnig veldur pað óhagræði og stundum meðferðartöf að almenn bráðamóttaka spítalans hefur eingöngu verið rekin í Fossvogi í nokkur ár pótt barnaspítali, hjartadeild og fleiri deildir sem annast meðferð og aðgerðir á sjúklingum með bráð mein í brjóstholi og kviðarholi séu á Hringbraut.

Árin 2007 til 2009 sat undirritaður í húsnæðisnefnd Landspítala. Pað var lærdómsríkt en lýjandi. Nefndin gekk um nær allar byggingar spítalans til að forgangsraða pví litla fjármagni sem bauðst til viðhalds ár hvert. Pær skipta tugum og eru dreifðar um borgina. Leki og rakavandamál eru útbreiddur vandi vegna ónógs viðhalds. Stórar álmur eins og A-álma Landspítala í Fossvogi halda ekki vatni. Pað eykur smithættu. Í A-álmunni er smitsjúkdómadeildin sem er, líkt og aðrir deildir spítalans, með allt of fá einbýli. Flestir eru á tvíbýli og daglegt brauð að sjúklingar liggi á gangi. Рað torveldar mjög varnir gegn smitandi veirum og bakteríum. Flestir verða að deila klósetti með öðrum, sem eykur líkur á smiti með tilheyrandi niðurgangsfaröldrum og tímabundnum lokunum deilda.

Rannsóknarstofur spítalans hafa verið reknar í lekum húskofum í bráðabirgðahúsnæði í rúm 36 ár. Sumar peirra eru raunar í míglekum húsum eins og sú sem greinir berklabakteríur og aðrar hættulegar og smitandi bakteríu- og veirusýkingar í Ármúla. Í geðdeildarbyggingunni við Hringbraut er leki einnig langtímavandi pótt húsið sé aðeins 35 ára gamalt. Enginn með réttu ráði léti hús sitt grotna niður með peim hætti sem Landspítali hefur mátt sætta sig við á síðasta áratug.

Nú hefur komið í ljós að myglusveppir hafa komið sér vel fyrir vegna leka á priðju hæð gamla spítalans við Hringbraut. Ýmislegt bendir til pess að myglan skýri langvinn og alvarleg einkenni sem starfsmenn með aðsetur á hæðinni hafa fundið fyrir í efri loftvegum. Heilsutjónið virðist mest hjá peim sem hafa varið par mestum tíma og hafa til dæmis purft að sofa par á vöktum. Sumir peirra munu líklega purfa ævilanga bólgumeðferð við loftvegasjúkdómi að sögn lækna sem hafa meðhöndlað pá. Vatn leitar gjarna niður á við. Gjörgæslan er í sömu álmu á næstu hæð fyrir neðan. Рað kostar mikið fjármagn að verja hana og pétta og purrka pykka veggi í pessari gömlu byggingu, reynist pað gerlegt. Starfsfólk Landspítala hefur sýnt fádæma langlundargeð í prengingum síðasta áratugar. Heilsuspillandi starfsumhverfi kann að verða kornið sem fyllir mælinn hjá sumum.

Húsnæðismál sameinaðs háskólasjúkrahúss hafa verið rædd og metin í meira en áratug. Nefnd á vegum Jóns Kristjánssonar, páverandi heilbrigðisráðherra, skilaði skýrslu um málið í janúar 2002. Niðurstaðan pá og við endurskoðun sérfræðinga hefur ávallt orðið sú að hagkvæmast sé að byggja við Hringbraut. Nú pegar öll leyfi fyrir byggingunni liggja fyrir parf að hefjast handa án tafar. Á pessari stundu er mikil óvissa um hvernig hægt verður að brúa bilið á Hringbraut par til nýr spítali rís. Ég spái að bráðabirgðaskúrum muni fjölga á lóðinni á árinu. Eiga peir eftir að standa í 36 ár eins og bráðabirgðahúsnæði rannsóknarstofa spítalans?

\section{Heimildir}

1. Sigurjónsson H. Vaxandi óánægja meðal sérfræðinga Landspítala. Læknablaðið 2012; 98: 600-2.

2. Jónsdóttir $\mathrm{P}$. Tækjabúnaður Landspítala: umhyggja - fagmennska - öryggi - frampróun? Læknablaðið 2012; 98: 447.

Risk of a crisis developing at Landspítali

Engilbert Sigurðsson, Editor-in-Chief of Læknablaðið, The Icelandic Medical Journal, Professor of Psychiatry, School of Health Sciences, University of Iceland, Consultant Psychiatrist Landspítali University Hospital. 